\title{
A transgenic mouse model for studying HBV infection in neonate
}

\author{
Zhuo Wang ${ }^{*}$, Qiang Deng, Ke Lan \\ From Institut Pasteur International Network Annual Scientific Meeting \\ Hong Kong. 22-23 November 2010
}

The human hepatitis B virus (HBV) infection is always a worldwide problem, especially the high risk infection of the neonate by chronically HBV infected mother. McGrane et al. [1] have demonstrated that the gene which is driven by the promoter of phosphoenolpyruvate carboxykinase (PEPCK) is mainly expressed in the mouse liver and immediately appears at parturition. We have constructed a transgenic mouse by using PEPCK promoter to drive the pre-S2 and S domain of HBV envelope protein to imitate HBV transmission from mother to child. We want to see whether hepatitis B surface antigen (HBsAg) can persistently exist or be cleared by immune system from the newborn mice.

Published: 10 January 2011

\section{Reference}

1. McGrane MM, Yun JS, Moorman AF, et al: Metabolic effects of developmental, tissue-, and cell-specific expression of a chimeric phosphoenolpyruvate carboxykinase (GTP)/bovine growth hormone gene in transgenic mice. J Biol Chem 1990, 265:22371-22379.

Submit your next manuscript to BioMed Central and take full advantage of:

- Convenient online submission

- Thorough peer review

- No space constraints or color figure charges

- Immediate publication on acceptance

- Inclusion in PubMed, CAS, Scopus and Google Scholar

- Research which is freely available for redistribution 